М. Г. Коваль, к.т.н., дочент, [0000-0001-6587-6677] Н. М. Фоміна, старший викладач, ${ }^{[0000-0001-5287-3733]}$ Г. С. Столяренко, д.m.н., професор, завідувач кафедри хімічних технологій и водоочищення e-mail:mismirkoval@gmail.com, radikal@ukr.net

Черкаський державний технологічний університет б-р Шевченка, 460, м. Черкаси, 18006, Україна

\title{
ВДОСКОНАЛЕННЯ ТЕХНОЛОГІЇ ОЧИЩЕННЯ СТІЧНИХ ВОД ФАРБУВАЛЬНО-ОЗДОБЛЮВАЛЬНОГО ВИРОБНИЦТВА ШЛЯХОМ ВПРОВАДЖЕННЯ ПРОЦЕСІВ КАВІТАЦІЇ Й ЕЛЕКТРОАКТИВАЦІЇ ТА МОЖЛИВОСТІ ПОВТОРНОГО ВИКОРИСТАННЯ СТІЧНИХ ВОД
}

Проблема очищення стічних вод з вмістом органічних барвників нині є актуальною. Діючі фарбувально-оздоблювальні текстильні виробництва не є ефективними і високорентабельними. У стічні води потрапляє велика кількість невикористаних барвників, які завдають значної шкоди екологічній системі водного регіону. Саме тому актуальною є проблема повторного використання стічних вод у технологічних прочесах текстильного виробництва (фарбування тканини) та глибокого очищення стічних вод иього виробництва.

У статті представлені результати аналізу стічних вод фарбувально-оздоблювального текстильного виробництвва після усереднення і розбавлення, а також виробничих стічних вод безпосередньо після процесу фарбування тканини (на виході фарбувальної установки). На основі одержаних результатів запропоновано технологію очищення виробничих стічних вод фарбувально-оздоблювального виробництва, що містять органічні барвники, із застосуванням процесів фільтрації, коагулячії і флокуляиії в кавітаторі, флотації та електроактивації для розробки ефективної технології водооборотних ииклів і повторного використання промислових стічних вод у технологічних процесах текстильного виробництва. Результати досліджень стічних вод отримані на дослідній установиі каскадного типу, стадії якої були розташовані над усереднювачем-відстійником діючих очисних споруд підприємства.

Аналіз стічних вод на виході фарбувальної установки дозволяє прогнозувати створення перспективної технології з перетворення промислових стічних вод у стан, придатний для повторного використання в технологічному циклі фарбування тканин. Реалізувавши таку технологію на практиці, можна вирішити завдання мінімізаиії витрат на дорогі барвники, досягти зниження собівартості текстильної продукиії при збереженні ї̈ якості, а також зменшення екологічної небезпеки відходів виробництва у вигляді стічних вод.

Ключові слова: фарбувально-оздоблювальне виробництво, стічні води, фільтрація, кавітація, коагуляиія, флотація, електроактивація, очищення, технологія водооборотних ичиклів.

Вступ. Відомо, що більшість діючих фарбувально-оздоблювальних виробництв побудовані на застарілих і недосконалих технологіях фарбування; їх стічні води є складними полідисперсними системами, що складаються з іонів, молекул барвників і допоміжних органічних речовин. Залежно від типу i властивостей текстильного барвника, що використовується, та способу фарбування тканини після завершення виробничого циклу в стічні води потрапляє від 20 до $50 \%$ барвників, що призводить до нанесення істотного збитку екологічній системі регіону, де розташовані такі виробництва. Внаслідок цього серед інших екологічних показників, що піддаються негативному впливу, слід виділити показник якості питної води $[1,2]$.

Необхідно відзначити, що проблема очищення стічних вод із вмістом барвників існує давно, проте на сьогодні немає достатніх відомостей про впровадження технологій, побудованих на нових принципах, які дозволяли б вирішувати таку проблему.

Спираючись на огляд і технологічні характеристики (особливо за залишковим вмістом речовин, 3 яких складаються барвники, в стічній воді), діючі фарбувально-оздоблювальні виробництва не можна назвати ефектив- 
ними і високорентабельними, тому що собівартість фарбування тканини значно залежить від вартості барвників і ступеня їх використання. Виходячи $з$ таких міркувань, стає очевидною актуальною потреба у формуванні двох напрямків досліджень стічних вод фарбувальнооздоблювальних виробництв:

- дослідження нових принципів глибокого очищення стічних вод, що містять органічні барвники, для досягнення високих екологічних показників;

- дослідження можливості повторного використання фарбувальних компонентів, що входять до складу стічних вод у технологічному циклі фарбувально-оздоблювального виробництва, для підвищення його економічної ефективності і високої рентабельності.

Мета дослідження. Визначення складу і фізико-хімічних властивостей стічних вод фарбувально-оздоблювального виробництва для пошуку нових підходів і принципів їх очищення; проведення дослідження з використання процесів кавітації і електроактивації для очищення стічних вод від барвників, що дозволять мінімізувати експлуатаційні витрати і вирішити проблему створення системи оборотного водопостачання підприємства; проведення експериментів 3 переведення стічної води зі стану з великим питомим вмістом барвників, що підлягає очищенню й утилізації, в стан, придатний для повторного використання в циклі фарбування тканини.

Виклад основного матеріалу. Коротка характеристика вихідної сировини. Відповідно до визначених цілей був сформульований основний критерій, що задовольняе умовам дослідження, який, в свою чергу, визначає оптимальні обмеження адсорбції речовин, що входять до складу барвника тканини, а також допоміжних речовин, наявних у стічних водах.

Для забезпечення поставлених цілей, а також для досягнення достовірності та високої ефективності досліджень як об'єкт досліджень були обрані стічні води фарбувальнооздоблювального виробництва ПрАТ «Черкаський шовковий комбінат» (м. Черкаси, Україна).

Предметом досліджень були обрані показники якості нанесеного на тканину барвника, залежно від складу стічної води, що дозволить повернути воду в оборотний цикл підприємства і забезпечить якість повторного фарбування.

Експериментальна частина досліджень проводилася в кілька етапів.

Так, на першому етапі для визначення способів і методів очищення стічних вод від барвників і допоміжних речовин було здійснено лабораторний аналіз стічних вод. Статистика аналізу стічної води наведена в таблиці 1. Дослідженню підлягали стічні води двох типів: стічні води після усереднення i розбавлення, тобто води, які за існуючою технологією відправляються в міські очисні системи, а також виробничі стічні води безпосередньо після процесу фарбування тканини (на виході фарбувальної установки). Проби усередненої і розбавленої стічної води відбиралися згідно з ГОСТ 31861-2012 і «Інструкцією з відбору проб для аналізу стічних вод НВН 33-5.3.01-85» протягом календарного року 3 часовими інтервалами, рівними тривалості кожного сезону.

Кількість проб стічної води визначалася кількістю тижнів (т. зв. щотижнева проба), а також - для підвищення достовірності статистичних даних - додатковою групою випадкових проб (8 проб у групі), отриманих протягом сезону спостережень. Таким чином, вибірка по кожному сезону складається з 20 проб, відповідно, за весь період річного спостереження були сформовані 4 сезонні вибірки.

У підсумку, протягом річного циклу досліджень було отримано 80 проб. При здійсненні аналізів враховувалися сезонність і продуктивність виробництва. Відібрані проби досліджувалися за існуючими методиками проведення аналізу ряду показників.

Залежність якості стічної води від сезонності визначається продуктивністю виробництва (кількістю сезонних замовлень), температурою навколишнього середовища (температурою повітря і води у відстійниках), швидкістю хімічних і біологічних процесів, що проходять у стічних водах при різних температурних режимах.

Згідно з вимогами виробництва і технічними характеристиками технології фарбування та набивання тканин [5] промислова стічна вода надходить у технологічний усереднювачвідстійник для відстоювання, після чого відводиться в міську каналізаційну систему для подальшого очищення міським комунальним підприємством. 
Таблиця 1 - Усереднені значення показників фізико-хімічного аналізу стічної води фарбувально-оздоблювального виробництва $[3,4]$

\begin{tabular}{|c|c|c|c|c|}
\hline \multirow{3}{*}{$\begin{array}{c}\text { Найменування показників, } \\
\text { одиниці розмірності }\end{array}$} & \multicolumn{4}{|c|}{ Сезонність } \\
\hline & $\begin{array}{c}\text { результати } \\
\text { взимку }\end{array}$ & $\begin{array}{c}\text { результати } \\
\text { весною }\end{array}$ & $\begin{array}{c}\text { результати } \\
\text { влітку }\end{array}$ & $\begin{array}{c}\text { результати } \\
\text { восени }\end{array}$ \\
\hline & \multicolumn{4}{|c|}{ Продуктивність виробництва } \\
\hline & $2054 \mathrm{~m}^{2}$ & $3169 \mathrm{~m}^{2}$ & $3400 \mathrm{~m}^{2}$ & $2699 \mathrm{M}^{2}$ \\
\hline Колір & $\begin{array}{l}\text { жовто- } \\
\text { зелений }\end{array}$ & сірий & $\begin{array}{l}\text { червоно- } \\
\text { рожевий }\end{array}$ & чорний \\
\hline Запах в балах & 3 & 3 & 3 & 4 \\
\hline Поріг розбавлення & $1: 6$ & $1: 6$ & $1: 6$ & $1: 6$ \\
\hline Осад та плаваючі домішки & пластівці & пластівці & немає & пластівці \\
\hline Прозорість за Снеллером, см & 4,2 & 4,4 & 4,8 & 3,8 \\
\hline $\begin{array}{c}\text { Температура в точці відбору } \\
\text { проби, }{ }^{\circ} \mathrm{C}\end{array}$ & $+12^{\circ} \mathrm{C}$ & $+16^{\circ} \mathrm{C}$ & $+20^{\circ} \mathrm{C}$ & $+15^{\circ} \mathrm{C}$ \\
\hline ПАР мг/л & 0,25 & 0,15 & 0,12 & 0,13 \\
\hline Зважені частинки, мг/л & 76 & 86 & немає & 34 \\
\hline Водневий показник, $\mathrm{pH}$ & 6,65 & 7,8 & 8,1 & 7,04 \\
\hline Прожарений залишок, мг/л & 491 & 491 & 520 & 500 \\
\hline Сухий залишок, мг/л & 450 & 1068 & 1128 & 670 \\
\hline Нітрати, мг/л & 4 & 5 & 4,5 & 10 \\
\hline Нітрити, мг/л & 0,8 & 0,9 & 0,7 & 0,8 \\
\hline Фосфати, мг/л & 1 & 0,49 & 1,2 & 2,87 \\
\hline Феноли, мг/л & 0,08 & 0,05 & 0,09 & --- \\
\hline Залізо загальне, мг/л & 1,10 & 1,61 & 0,44 & 1,25 \\
\hline Мідь, мг/л & 0,1 & 0,1 & 0,12 & $\begin{array}{c}-- \\
-\end{array}$ \\
\hline Азот амонійний, мг/л & 21,67 & 5,34 & 6,63 & 14,04 \\
\hline Хром 6+ & 0,06 & 0,05 & 0,09 & --- \\
\hline $\mathrm{XCK,} \mathrm{мг} \mathrm{O}_{2} /$ л & 730 & 235 & 209 & 510 \\
\hline Нікель, мг/л & 0,1 & 0,12 & 0,11 & --- \\
\hline Марганець, мг/л & 0,2 & 0,18 & 0,23 & --- \\
\hline
\end{tabular}

За результатами аналізу можна зробити висновок, що досліджувана стічна вода фарбувально-оздоблювального виробництва за багатьма показниками не відповідає нормам, має колір, часто неприємний специфічний запах і потребує інтенсивного очищення.

Для визначення можливості повторного використання стічних вод у виробничих процесах, залежно від кількості барвників у їх складі, були досліджені проби виробничих стічних вод, відібраних до і після циклу фарбування різних тканин фарбувальними ваннами 3 прямими барвниками в автоматичних машинах супер-Джигер VN фірми «Хенріксен» (Данія).

Прямі барвники належать до водорозчинних барвників і $є$ натрієвими солями органічних сульфокислот. Вони мають спорід- неність із целюлозними волокнами (бавовна, льон, штучні волокна $з$ регенерованої целюлози) і фарбують їх безпосередньо з водного розчину в присутності електролітів, які переходять на волокно у вигляді солей $[6$, (c. 40-41), 3].

Результати досліджень наведені в таблиці $2[7,8]$.

Відібрані проби аналізувалися на вміст у них текстильних барвників. Оскільки колір барвника залежить від його взаємодії зі світлом, то кількісне оцінювання його наявності в стічній воді проводили методом фотоколориметрії 3 подальшими аналітичними розрахунками за законом Бугера-Ламберта-Бера [6]. Фотометричний аналіз виконувався за допомогою фотоелектричного спектрофотометра UV-5800PC. 
Таблиця 2 - Аналіз стічних вод процесу фарбування тканин текстильними барвниками

\begin{tabular}{|c|c|c|c|c|c|}
\hline Барвник & $\begin{array}{l}\text { Концентрація } \\
\text { барвника у } \\
\text { фарбувальній } \\
\text { ванні до фар- } \\
\text { бування, г/л }\end{array}$ & $\begin{array}{l}\text { Концентрація } \\
\text { барвника у } \\
\text { фарбувальній } \\
\text { ванні після } \\
\text { фарбування, } \\
\text { г/л }\end{array}$ & $\begin{array}{l}\text { Кількість барв- } \\
\text { ника, яка за- } \\
\text { лишилася у } \\
\text { стічній воді, \% }\end{array}$ & $\begin{array}{l}\text { Вартість } 1 \text { кг } \\
\text { барвника, \$ }\end{array}$ & $\begin{array}{l}\text { Вартість бар- } \\
\text { вника, який } \\
\text { викидається } \\
\text { iз стічними } \\
\text { водами, \$ }\end{array}$ \\
\hline \multicolumn{6}{|c|}{ Зразок № 1 (склад тканини: 78 \% бавовна , 22 \% поліефір) - колір пофарбованої тканини чорний } \\
\hline $\begin{array}{c}\text { Прямий } \\
\text { чорний } \\
\text { VSV }\end{array}$ & $2,44 \cdot 10^{-4}$ & $8,63 \cdot 10^{-5}$ & 35,3 & 166,22 & 775,75 \\
\hline \multicolumn{6}{|c|}{ Зразок № 2 (склад тканини: 100 \% віскоза) - колір пофарбованої тканини темно-синій } \\
\hline $\begin{array}{c}\text { Прямий } \\
\text { синій } \\
\text { B2RL } \\
\end{array}$ & $3,44 \cdot 10^{-5}$ & $1,89 \cdot 10^{-5}$ & 54,88 & 328,28 & 288,23 \\
\hline $\begin{array}{l}\text { Прямий } \\
\text { голубий } \\
\text { 5В }\end{array}$ & $1,92 \cdot 10^{-5}$ & $1,11 \cdot 10^{-5}$ & 57,9 & 223,20 & 139,56 \\
\hline $\begin{array}{c}\text { Прямий } \\
\text { чорний } \\
\text { VSF }\end{array}$ & $7,4 \cdot 10^{-6}$ & $3,9 \cdot 10^{-5}$ & 52,7 & 166,22 & 35,06 \\
\hline \multicolumn{6}{|c|}{ Зразок № 3 (склад тканини: 100 \% бавовна) - колір пофарбованої тканини червоний } \\
\hline $\begin{array}{c}\text { Прямий } \\
\text { помаран- } \\
\text { чевий S }\end{array}$ & $1,4 \cdot 10^{-4}$ & $3,88 \cdot 10^{-5}$ & 27,6 & 185,03 & 409,1 \\
\hline
\end{tabular}

Беручи до уваги дані з таблиці 2, можна зробити висновок, що бавовняна тканина краще вбирає барвник із фарбувальної ванни, ніж сумішеві (78 \% бавовна, $22 \%$ поліефір) віскозна. Це обумовлено кращими адсорбційними властивостями бавовняного волокна [5]. Кількість барвників, які після процесу фарбування залишаються в стічних водах, становить 46-50 \% (середнє значення), що ще раз, але вже шляхом експериментального дослідження, обгрунтовує теоретичну можливість і практичну необхідність створення перспективної технології з перетворення промислових стічних вод в стан, придатний для повторного використання в технологічному циклі фарбування тканин.

Цінність таких висновків полягає в тому, що, реалізувавши таку технологію на практиці, вирішується завдання мінімізації витрат на дорогі барвники, зниження собівартості текстильної продукції при збереженні iii якості, а також зменшення екологічної небезпеки відходів виробництва у вигляді стічних вод.

Технологія водоочищення на підприємстві. Промислові стоки фарбувально-оздоблювального виробництва надходять 3 кількох гілок каналізацій у багатокоридорний усереднювачвідстійник, який є єдиною очисною спорудою перед скиданням стічних вод у міську каналізаційну систему. Подальше розбавлення їх водами міської каналізації - природний захист мікроорганізмів на централізованих міських біологічних очисних спорудах. Для досягнення вимог, що висуваються до води, яка скидається в каналізацію, у відстійник для перемішування, флотації та часткового окиснення органічних сполук подається повітря. Крім того, використовується багаторазове розбавлення водопровідною питною водою. Таким чином, фактична продуктивність усереднювача-відстійника (час усереднення - до 24 годин) становить від $1400 \mathrm{~m}^{3}$ до $3000 \mathrm{~m}^{3}$ на добу, а стічна вода характеризується значною різноманітністю за складом і якістю забруднювачів.

За даними контролю була досягнута наступна ефективність роботи споруд: ГДК знижувалася на 32-44 \%; БСК - на 26-38,6 \%, вміст барвників - на 65,6-88,4\%. Для досягнення вимог до води, що подається в міську каналізацію, необхідний максимальний поріг розбавлення досягає 52-64 рази. 
Результати лабораторних досліджень по очищенню стічних вод. На другій стадії в лабораторних умовах були проведені дослідження по фільтрації, флокуляції, коагуляції і прямому озонуванню різного складу стічних вод.

На підставі проведених досліджень було встановлено наступне:

1. Очищення води фільтрацією на традиційних фільтруючих тканинах і матеріалах, a також на зворотноосмотичних ультрафільтраційних стандартних установках реальних стічних вод неможливе, тому що спостерігається швидке наростання плівки барвника на поверхні фільтра, різке зростання гідравлічного опору системи і припинення фільтрації. «Зафарбовування〉 фільтруючої поверхні за 2,4-3,2 години пов'язане 3 наявністю зважених речовин барвника; регенерація фільтруючих поверхонь технологічно недоцільна - вона неможлива без застосування органічних розчинників. На підставі проведених дослідів із фільтрацією було вирішено вивчити можливість застосування як фільтруючої поверхні пухкого та пористого матеріалу, що дозволяє і фільтрувати, і адсорбувати барвник одночасно.

Вимоги технічних показників до адсорбентів є такими: низька вартість, висока питома фільтруюча поверхня, можливість регенерації або утилізації після фільтрації або адсорбції барвника, відсутність ефекту вторинного забруднення. Саме ці якості притаманні пилу і тирсі листяних порід дерев. Відповідно до попереднього експерименту вирішено було використовувати середню фракцію тирси фанерного цеху деревообробного комбінату.

2. Проведення процесу коагуляції та флокуляції для досягнення необхідних показників за змістом полютантів у воді призводить до непродуктивної витрати реагентів до 2,7 тонн в рік; активне зниження кольоровості і ГДК відбувається при відносно високих дозах флокулянта - до 1 мг на 500 мг $\mathrm{O}_{2}$ за ГДК або до 1 мг на $1700 \%$ кольоровості. Вартість прямого флокуляційного очищення (до 4 млн. \$ США на рік) не дає можливості рекомендувати останню у виробництво.

3. Перед озонуванням для отримання коректних результатів проби стічних вод піддавалися 5-кратному розведенню дистильованою водою. Пряме озонування стічних вод економічно недоцільне через високі витрати окиснювача і тривалий час контакту фаз. Для проведення процесу озонування після фільт- рації через необхідність попереднього очищення від зважених і колоїдних частинок барвника доза озону становила $20 \ldots 25 \Gamma / \mathrm{m}^{3}$, час контакту води з озоно-повітряною сумішшю $30 \ldots 45$ хвилин, вартість очищення $1 \mathrm{~m}^{3}$ при цьому перевищує 1 млн \$ США в рік.

Результати досліджень по очищенню стоків на стендовій дослідній установиі. Для вирішення поставленої мети на промисловому усереднювачі було сконструйовано і споруджено дослідну каскадну установку 3 очищення стічних вод. Установка складалася 3 таких стадій: фільтрація на намивному фільтpi, коагуляція і флокуляція в кавітаторі, флотація, а далі - відстоювання і електроактивація. Перші три стадії були встановлені безпосередньо над усереднювачем. Далі очищена вода надходила в лабораторію на установки по відстоюванню і електроактивації.

Фільтр формували на сітчастій стрічці 3 вологої деревної тирси, змішаної $з$ деревним пилом листяних порід дерев. Оптимальні витратні норми по сухій речовині фільтрувального матеріалу $-0,1-0,5$ кг/ $\mathrm{m}^{3}$.

Кавітаційна підготовка суспензії коагулянту здійснювалася за власною технологічною схемою. Для більшості барвників як коагулянт застосовувався $5 \%$ розчин (суспензія) кальцій гідроксиду. За необхідністю в об'єм відстійника додавався $1 \%$ розчин флокулянта ВПК-402 з дозою до 50 мг на 1 м $^{3}$ води.

Коагуляція і флотація здійснювалися в перших двох секціях усереднювача стічних вод шляхом перемішування із застосуванням повітряного барботажу.

У процесі проведення експериментів на дослідній установці, розташованій на усереднювачі, і наступних двох стадій в лабораторних умовах було встановлено, що за всіма необхідними нормами: за кольоровістю, прозорістю, ГДК і БСК досягнуті показники, що відповідають нормам прийому стічних вод на біологічних очисних спорудах.

Процес спільного очищення приводить до досить значного знебарвлення (90\%), зростання прозорості (в $5 \ldots 7$ разів), зниження вмісту завислих речовин (60\%). Причому, для води, забарвленої в чорно-сині тони, доза флокулянта може бути знижена до нуля. Для червоних і червоно-синіх тонів води доза флокулянта ВПК-402 становить $0,05-0,14$ г/ $\mathrm{m}^{3}$ i залежить від ступеня забруднення води $[9,10]$.

Результати досліджень, отриманих при очищенні стоків, представлені в таблиці 3. 
Таблиця 3 - Експериментальні дані, отримані на дослідній установці з очищення стічних вод методами фільтрації, коагуляції під дією кавітатора, флокуляції та відстоювання

\begin{tabular}{|l|c|c|c|}
\hline \multicolumn{1}{|c|}{ Параметри $^{*}$} & $\begin{array}{c}\text { Вихідна вода } \\
\text { із усереднювача }\end{array}$ & Після очищення & Після відстоювання \\
\hline Колірність, \% & 1585 & 160 & 65 \\
& 1730 & 180 & 60 \\
& 1850 & 180 & 70 \\
\hline Прозорість, см & 2180 & 200 & 80 \\
& 3,0 & 14 & 15 \\
& 3,2 & 14 & 15 \\
& 3,3 & 15 & 17 \\
рН & 3,6 & 17 & 18 \\
& 7,66 & 7,66 & 7,64 \\
& 7,78 & 7,68 & 7,08 \\
& 7,88 & 7,90 & 7,90 \\
\hline Температура t, ${ }^{0} \mathrm{C}$ & 7,90 & 7,92 & 22 \\
\hline ХСК, мг $\mathrm{O}_{2} /{ }^{3}$ & 24 & 160 \\
& $23-25$ & 180 & 150 \\
& 200 & 169 & 360 \\
& 500 & 368 & 350 \\
\hline Зважені речовини, & 460 & 370 & 20,2 \\
мг/дм $^{3}$ & 64,2 & 26,6 & 28,6 \\
& 64,0 & 32,4 & 32,0 \\
& 82,4 & 36, & 38,7 \\
\hline
\end{tabular}

Примітка:* Вміст важких металів, твердість і лужність практично не змінювалися; сухий залишок знижувався на 35-42 \%.

Шляхом виконання регулярних експериментів було встановлено, що зниження ГДК і БСК на стадії електроактивації дає технологічну можливість повернути очищені стоки назад у виробництво.

На підставі отриманих експериментальних даних розроблено технологічну схему очищення води.

Принципова технологічна схема очищення промислової стічної води зображена на рисунку 1. Стічна вода 1 фарбувального виробництва надходить по трубопроводу в першу секцію 3 чотирикоридорного усереднювача 2. Вода подається через намивний фільтр 4. Фільтруючий шар формується по лініях $5,6,7$, а відводиться на утилізацію по лініях 8,9 .

В усереднювач додається $1 \%$ розчин флокулянта 11, приготовлений за стандартною схемою 13 , і суспензія $5 \%$-го розчину коагулянту 10 , змішаного 3 тирсою. Підготовка намивного фільтра здійснюється за власною технологічною схемою 6 . У першу секцію подається стиснене повітря 12 для змішу- вання реагентів і прискорення процесів коагуляції і флотації. Розчини коагулянту і флокулянта подаються в усереднювач через кавітатори 14 і 15. Під дією реагентів зважені і колоїдні речовини, що знаходяться в стоках, коагулюють і утворюють осад, який осідає в другій і третій секціях усереднювача. Піна i зважені частинки видаляються після флотації через кишені 16 і разом з осадом відправляються на утилізацію 17. Осад механічним шляхом видаляється на утилізацію у вигляді шламу. Насосами 18 і 19 очищена вода подається в системи підготовки розчинів флокулянтів і коагулянтів, а також в систему електроактивації 20-30. В електроактиваторі 23 відбувається остаточна обробка стоків, після чого вода повертається у виробництво 31.

Після стадії електроактивації вода може бути використана при повторному технологічному циклі фарбування волокнистих матеріалів. Таким чином, запропонована технологічна схема дає можливість повністю повернути стічні води без їх подачі на біологічні очисні споруди. 


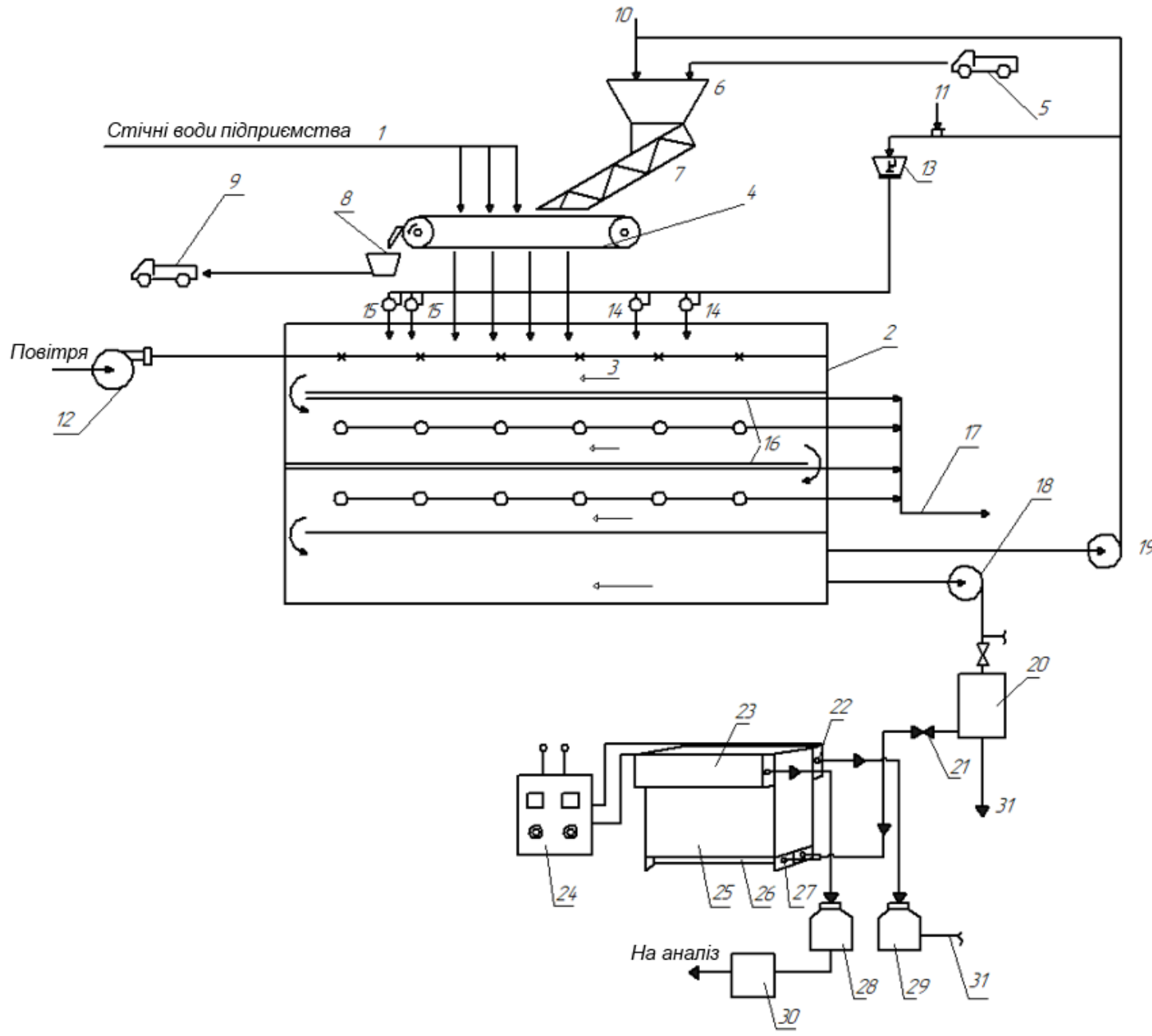

1 - колектор стічних вод; 2 - чотирикоридорний усереднювач; 3 - секція коагуляції і флокуляції; 4 - намивний фільтр; 5, 9 - транспорт; 6 - бункер завантаження фільтруючого агента;

7 - стадія підготовки і дозування фільтруючого агента; 8 - приймач відпрацьованого матеріалу, що фільтрує; 10, 11 - подача коагулянту і флокулянта; 12 - подача стисненого повітря; 13 - дозатор розчину коагулянту; 14,15 - кавітатори; 16 - кишені видалення піни; 17 - відведення шламу і агломерату

на утилізацію; 18, 19 - насоси; 20 - ємність 3 досліджуваною водою; 21 - засувка; 22 - штуцер;

23 - камера для відведення води; 24 - блок живлення; 25 - ємність електроактиватора; 26 - камера для підведення води; 27 - штуцер; 28 - ємність для католіту; 29 - ємність для аноліту; 30 - відстійник аноліту; 31 - повернення води у виробництво

Рисунок 1 - Принципова технологічна схема очищення промислової стічної води

Висновки. Отримані дані досліджень дозволяють сформулювати такі висновки:

1. Експериментально доведено, що стічні води фарбувально-оздоблювальних виробництв містять у своєму складі значну кількість невикористаних барвників, що обгрунтовує практичну необхідність створення перспективної технології для повторного використання їх у технологічному циклі фарбування тканин.

2. Результати дослідження із використанням процесів фільтрації на намивному фільтрі, а також кавітації для очищення стічних вод від барвників свідчать про можливе використання цього методу для якісного очищення промислової стічної води.

3. Запропонований метод кавітаційного очищення і стадія електроактивації води дають можливість після утилізації барвників використовувати воду у повторному технологічному циклі фарбування; повторне використання зворотної води в циклі фарбування не впливає на якість фарбування.

4. Пропонована технологія дозволяє мінімізувати експлуатаційні витрати і вирішити проблему створення системи оборотного водопостачання підприємства. 


\section{Список літератури}

[1] А. Я. Ефимов, Очистка сточных вод предприятий легкой промышленности. Киев: Техника, 1985.

[2] В. А. Проскуряков, и Л. И. Шмидт, Очистка сточных вод в химической промышленности. Ленинград: Химия, 1977.

[3] О. О. Саніна, та М. Г. Коваль, "Дослідження стічних вод текстильно-фарбувального виробництва", на $I X$ обл. молодіж. наук.-практ. конф. Управління водними ресурсами Черкащини та шляхи їх раціонального використання, Черкаси, грудень, 2018, с. 31-32.

[4] В. Г. Кузьменко, А. М. Поздишева, та М. Г. Коваль, "Дослідження промислових стічних вод фарбувального виробництва 3 можливістю їх повторного використання", на V Всеукр. міжвуз. наук.-практ. конф. СДУ, Суми, 17-20 квітня, 2018, c. $245-246$.

[5] Ф. И. Садов и др., Химическая технология волокнистых материалов. Москва: Легкая индустрия, 1968.

[6] В. Ф. Бородкин, Химия красителей: учебник. Москва: Химия, 1981.

[7] А. М. Поздишева, та М. Г. Коваль, "Дослідження повторного використання промислових стічних вод фарбувального виробництва", на студ. наук.-практ. конф. ЧДТУ, Черкаси: ЧДТУ, 16-19 квітня, 2018, c. 15.

[8] М. Г. Коваль, та А. М. Поздишева, "Дослідження повторного використання промислових стічних вод в технології фарбування текстильних матеріалів прямими барвниками", на $I V$ Міжнар. наук.-практ. конф. Концептуальні шляхи розвитку науки, Київ, 30-31 березня 2019, с. 45-46.

[9] Г. С. Столяренко, та М. Г. Коваль, "Розробка технології очищення стічної води фарбувально-оздоблювального виробництва із застосуванням кавітаційних процесів", на Вісімнад. Міжнар. наук.-практ. конф. Ресурси природних вод карпатського регіону (Проблеми охорони та раціонального використання), Львів, 2324 травня 2019. с. 152-156.

[10] Н. М. Фомина, М. Т. Коваль, Ф. Р Азизов, и Г. С. Столяренко, "Исследование возможности применения кавитационных процессов при разработке перспективной технологии очистки сточных вод кра- сильно-отделочного производства и их повторного использования", Политехнический вестник. № 1 (45), с. 54. Душанбе, 2019, ТТУ.

\section{References}

[1] A. Ya. Efimov, Wastewater treatment of light industry enterprises. Kiev: Tehnika, 1985 [in Russian].

[2] V. A Proskuryakov, and L. I. Schmidt, Wastewater treatment in the chemical industry. Leningrad: Himiya, 1977 [in Russian].

[3] O. O. Sanina, and M. G. Koval, "Research of sewage of textile and dyeing production", in IX Regional Youth Sci.-Pract. Conf. Management of Water Resources of Cherkasy Region and Ways of their Rational Use", pp. 31-32, 2018 [in Ukrainian].

[4] V. G. Kuzmenko, A. M. Pozdisheva, and M. G. Koval, "Research of industrial sewage of dye production with the possibility of their reuse", in V All-Ukr. Inter-University Sci.-Pract. Conf. of the SGU, 2018, pp. 245246 [in Ukrainian].

[5] F. I. Sadov, et al., Chemical technology of fibrous materials. Moscow: Lyogkaya industriya, 1968 [in Russian].

[6] V. F. Borodkin, Chemistry of dyes: textbook. Moscow: Himiya, 1981 [in Russian].

[7] A. M. Pozdisheva, and M. G. Koval, "Research of reuse of industrial sewage of dye production", in Student Sci.-Pract. ChDTU Conf., 2018, p. 15 [in Ukrainian].

[8] M. G. Koval, and A. M. Pozdysheva, "Research of reuse of industrial sewage in technology of dyeing of textile materials by direct dyes", in IV Internat. Sci.-Pract. Conf. Conceptual ways of development of science, 2019, pp. 45-46 [in Ukrainian].

[9] G. S. Stolyarenko, and M. G. Koval, "Development of technology of sewage treatment of dyeing and finishing production using cavitation processes", in Eighteenth Internat. Sci.-Pract. Conf. Natural Resources of the Carpathian Region (Problems of Protection and Rational Use), 2019, pp. 152156 [in Ukrainian].

[10] N. M. Fomina, M. G. Koval, F. R. Azizov, and G. S. Stolyarenko, "Investigation of the possibility of using cavitation processes in the development of promising technology for sewage treatment and dyeing and their reuse", Politehnicheskiy vestnik. no. 1 (45), p. 54. Dushanbe, 2019 [in Russian]. 
M. G. Koval, Ph. D., associate professor,

N. M. Fomina, senior lecturer,

G. S. Stolyarenko, D. Sc., professor, the head of the department

of chemical technologies and water purification,

Cherkasy State Technological University

Shevchenko blvd, 460, Cherkasy, 18006, Ukraine

\section{IMPROVEMENT OF THE TECHNOLOGY OF WASTEWATER TREATMENT OF DYEING AND FINISHING PRODUCTION BY THE IMPLEMENTATION OF CAVITATION AND ELECTROACTIVATION PROCESSES AND THE POSSIBILITY OF WASTEWATER USE}

The problem of sewage treatment with the content of organic dyes is urgent now. Existing dyeing and finishing textile industries are not efficient and highly profitable. Wastewater enters a large number of unused dyes, which cause significant damage to the ecological system of the water region. That is why the problem of reuse of wastewater in technological processes of textile production (dyeing of fabric) and deep purification of wastewater of this production is urgent.

The article presents the results of the analysis of sewage dyeing and finishing textile production after averaging and dilution, as well as production sewage immediately after the fabric dyeing process (at the outlet of the dyeing plant). Based on the obtained results, the technology of wastewater treatment of dyeing and finishing production containing organic dyes is proposed, using the processes of filtration, coagulation and flocculation in the cavitator, flotation and electroactivation for the development of effective technology of water cycle and reuse of industrial processes textile production. The results of sewage research are obtained at the cascade type pilot plant, the stages of which have been located above the sump of the existing sewage treatment plant.

The analysis of sewage at the outlet of the dyeing plant allows to predict the creation of promising technology for the conversion of industrial wastewater into a state suitable for reuse in the technological cycle of dyeing fabrics. Having implemented such technology in practice, the problem of minimizing the cost of expensive dyes, reducing the cost of textile products while maintaining its quality, as well as reducing the environmental hazard of waste in the form of wastewater is solved.

Keywords: dyeing and finishing production, sewage, filtration, cavitation, coagulation, flotation and electroactivation, purification, technology of water-cycles.

Стаття надійшла 02.09.2019

Прийнято 20.09.2019 